\title{
State Sovereign Immunity and Stare Decisis: Solving the Prisoners' Dilemma within the Court
}

\author{
Neil S. Siegel $\uparrow$
}

I remain convinced that Union Gas was correctly decided and that the decision of five Justices in Seminole Tribe to overrule that case was profoundly misguided. Despite my respect for stare decisis, I am unwillimg to accept Seminole Tribe as controlling precedent....[B]y its own repeated overruling of earlier precedent, the majority has itself discounted the importance of stare decisis in this area of the law. The kind of judicial activism manifested in cases like Seminole Tribe, [Alden, and the two College Savings Bank Cases] represents such a radical departure from the proper role of this Court that it should be opposed whenever the opportunity arises. ${ }^{1}$

This Comment argues that the liberal and conservative blocs on the U.S. Supreme Court are embroiled in a Prisoners' Dilemma with respect to whether they should follow precedent on the question of congressional abrogation of state sovereign immunity. The analytical consequence of this strategic situation within the Court is that, over the long run, all of the Justices would more fully realize their views of the merits of Eleventh Amendment cases by demonstrating more-not less-respect for the independent value of stare decisis. This Comment uses game theory to substantiate this claim, after which it offers a potential, contingent solution to the collective action problem that the Justices face. Most importantly,

Copyright ( 2001 California Law Review, Inc. California Law Review, Inc. (CLR) is a California nonproft corporation. CLR and the authors are solely responsible for the content of their publications.

$\dagger \quad$ Law Clerk to the Honorable J. Harvie Wilkinson IIl, Chief Judge, United States Court of Appeals for the Fourth Circuit, Charlottesville, Virginia; J.D., School of Law, University of California, Berkeley (Boalt Hall), 2001; Ph.D. (Jurisprudence \& Social Policy) University of California, Berkeley, 2001; M.A. (Economics), Duke University, 1995; A.B. (Economics and Political Science), Duke University, 1994. I am grateful to Bob Cooter, Paul Mishkin, and especially Robert Post for critical feedback on carlier drafts, as well as the editors of the Califormia Law Review for their fine editorial hands. I dedicate this Comment to Paul Mishkin and Robert Post, mentors and friends who have taught me an awful lot about federalism, and who have instilled in me the aspiration that law be more than politics.

1. Kimel v. Fla. Bd. of Regents, 528 U.S. 62, $97-99$ (2000) (Stevens, J., dissenting) (citations and footnote oinitted). 
however, by focusing on the strategic dimension of stare decisis and identifying the long-term effects of the Court's tendency to overrule decisions when, and only because, a change in its composition empowers a new majority that thinks the precedent was wrongly decided, this inquiry brings into focus a significant hiatus in the current legal debate over the constitutional status of state sovereign immunity.

\section{INTRODUCTION}

In announcing the judgment of the Court in Planned Parenthood $v$. Casey, ${ }^{2}$ Justices O'Connor, Kennedy, and Souter approvingly quoted Justice Stewart for the proposition that

"A basic change in the law upon a ground no firmer than a change in our membership invites the popular misconception that this institution is little different from the two political branches of the Government. No misconception could do more lasting injury to this Court and to the system of law which it is our abiding mission to serve." $" 3$

Justice Scalia has made a frontal assault on this proposition. In South Carolina v. Gathers, ${ }^{4}$ he argued that Booth v. Maryland, ${ }^{5}$ which prohibited a jury from considering a victim impact statement at a capital sentence hearing, should be overruled, asserting his "doubt that overruling Booth will so shake the citizenry's faith in the Court," and observing that "[o]verrulings of precedent rarely occur without a change in the Court's personnel." Moreover, in his separate opinion in Payne v. Tennessee, ${ }^{8}$ which overruled Booth, he suggested that a decision of the Court may legitimately be overruled for no more compelling reason than that it was wrongly decided.9

2. 505 U.S. 833 (1992).

3. Id. at 864 (quoting Mitchell v. W.T. Grant, 416 U.S. 600, 636 (1974) (Stewart, J., dissenting)).

4. 490 U.S. 805 (1989).

5. 482 U.S. 496 (1987).

6. Gathers, 490 U.S. at 824 (Scalia, J., dissenting).

7. Id. Justice Scalia was responding to the argument "that we should not overrule so recent a decision, lest our action 'appear to be ... occasioned by nothing more than a change in the Court's personnel,' and the rules we announce no more than 'the opinions of a small group of men who temporarily occupy high office."' Id. (quoting Brief Amicus Curiae of Professors of Law Barbara Babcock et al. as Amicus Curiae 29-30 (No. 88-305) (quoting Fla. Dept. of Health and Rehabilitative Serv. v. Fla. Nursing Home Ass'n, 450 U.S. 147, 154 (1981) (Stevens, J., concurring))).

8. 501 U.S. 808 (1991).

9. See id. at 834 , in which Justice Scalia stated, "what would enshrine power as the governing principle of this Court is the notion that an important constitutional decision with plainly inadequate rational support must be left in place for the solc reason that it onee attraeted five votes." Justice Scalia's formulation should not obfuscate what he is really suggesting-namely, that a current majority may legitimately overnule a previous decision of the Court because it thinks that it was wrongly decided, at least in "important" cases. This follows because it is highly unlikely that a Justice would view a decision as wrongly decided and yet conclude that it possessed adequate rational support. 
The significance of Justice Scalia's approach is pointed out by Daniel Meltzer, who has observed that "overruling simply to correct a perceived mistake would drain stare decisis of any force whatsoever."10 This consequence matters greatly because stare decisis serves such fundamental ruleof-law values as replicability, stability, and consistency. ${ }^{11}$ Maintaining those values in the practice of constitutional adjudication is particularly important because the Constitution's authority to limit state action derives in large measure from its status as law. ${ }^{12}$ As Robert Post has written while identifying "doctrinal" constitutional interpretation as appealing to "the authority of the Constitution as law"13.

There is, first, the authority of the Constitution as law. The Constitution controls state actions because the Constitution is the highest law, above all merely quotidian state activity. ...

If the Constitution predominates because it is law, its interpretation must be constrained by the values of the rule of law, which means that courts inust construe it through a process of reasoning that is replicable, that remams fairly stable, and that is consistently applied. In American adjudication the principle of stare decisis has been an essential component of the rule of law. The principle is of particular importance on those occasions when constitutional adjudication mvolves vague textual referents (like "equal protection of the laws," or "due process of law"), with regard to which there is "only limited evidence of exactly how the Framers intended the [text] to apply." On these occasions the principle of stare decisis holds courts to a consistent and stable interpretation of [the] Constitution.

Without such consistency and stability, it would be difficult to understand the Constitution as having any existence as law. ${ }^{14}$

Dismantling stare decisis would significantly erode the Constitution's existence as a species of law, and thus its legitimate authority to articulate

10. Daniel J. Meltzer, The Seminole Decision and State Sovereign Immunity, 1996 SuP. CT. REv. 1,30 .

11. See Melvin Aron Eisenderg, The NATURE of the COMMON LAW 47-49 (1988); J.M. Balkin, Constitutional Interpretation and the Problem of History, 63 N.Y.U. L. REV. 911 , 928 (1988).

12. The Constitution is superior to and therefore controls state actions because it is the fundamental law; that is, it is the highest law in the land. This is precisely the form of authority to which Chief Justice Marshall appealed in establishing the institution of judicial review in Marbury $v$. Madison, 5 U.S. (1 Cranch) 137 (1803), when he wrote that "[t]he constitution is a superior paramount law, unchangeable by ordinary means," $i d$. at 177, as a consequence of which "an act of the legislature, repugnant to the constitution, is void." Id. Judges may appeal to the authority of the Constitution as law in rendering constitutional decisions because "[i]t is emphatically the province and duty of the judicial department to say what the law is." Id.

13. Robert Post, Theories of Constitutional Interpretation, 30 REPRESENTATIONS 13, 19 (1990), reprinted in Robert C. Post, Constitutional Domains: Democracy, Community, Management 23 (1995).

14. Id. (quoting Minneapolis Star and Tribune Co. v. Minn. Comm'n of Revenue, 460 U.S. 575 , 583 n.6 (1983)) (footnotes omitted). 
fundamental ties that bind. There is therefore a great deal at stake in whether the Court adopts Justice Stewart's or Justice Scalia's stated view in the years to come-especially in light of the reality that President George W. Bush almost certainly will put one Justice on the Court, and very conceivably could end up nominating three or more before his presidency has drawn to a close. ${ }^{15}$ In virtue of the critical moment in constitutional history at which our nation finds itself, Justice Scalia's reminder that changes in constitutional doctrine tend to follow changes in the Court's composition ${ }^{16}$ is portentous in its implications for the future.

Stare decisis is normally thought of in the context of the rule-of-law values identified and discussed above. That concerns the substance of stare decisis-its content in any particular case. But game theory has taught the legal community to consider judicial behavior in other dimensions, most notably the strategic one. This lens is particularly appropriate when divisions within the Court in a particular area of the law become so entrenched and persistent that the Court has fractured into blocs which view each other in that legal context, not as participants in cominon enterprise, but as agents with conflicting interests. When disagreement within the Court becomes so violent as to inpart these effects, strategic analysis is necessary in order to determine the long-run stability of decisions that reflect-and only reflect-the governing majority coalition's view of the inerits of given cases. That is, in circumstances of deep, irreconcilable conflict between the two wings of the Court, it may turn out that each side would do better in terms of realizing its substantive views on certain legal questions by paying greater respect for stare decisis than historically has been the case, even in situations in which the precedent at issue involves a decision on the merits with which the governing majority disagrees. A strategic analysis of stare decisis is useful in helping to determine whether-and the circumstances under which-this situation may obtain in a particular area of the law.

A contemporary area of the Court's jurisprudence that has begun to assume dimensions of intense, stable disagreement is its Eleventh Amendment decisions. ${ }^{17}$ In the state sovereign immunity cases ${ }^{18}$ (and those

15. Justice Stevens tumed 81 years of age on April 20, 2001. Chief Justice Rehnquist will be 77 years of age on October 1, 2001, and Justice O'Connor celebrated her 71st birthday on March 26, 2001.

16. See supra text accompanying note 7.

17. See supra note 1 .

18. See Seminole Tribe v. Florida, 517 U.S. 44 (1996) (holding unconstitutional the Indian Gaming Regulatory Act (IGRA) because Congress does not possess the constitutional power, when acting under Article 1, to abrogate a state's immunity from suit in federal court), overruling Pennsylvania v. Union Gas Co., 491 U.S. 1 (1989); Idaho v. Coeur d'Alene Tribe, 521 U.S. 261 (1997) (holding that Eleventh Amendment precluded prospective relief against state officers who were interfering with plaintiff tribe's alleged property rights in submerged lands because tribe's suit was functional equivalent of quiet title action against state, which would prevent exercise of state regulatory authority over lands); Fla. Prepaid Postsecondary Educ. Expense Bd. v. College Sav. Bank, 527 U.S. 627 (I999); College Sav. Bank v. Fla. Prepaid Postsecondary Educ. Expense Bd., 527 U.S. 666 (1999); Alden v. Maine, 527 U.S. 706 (1999) (extending Seminole's holding to suits commenced in state 
concerning federalism more generally ${ }^{19}$ ), the five-to-four votimg pattern and overrulings of precedent have become as predictable as the New York Yankees winning the World Series. ${ }^{20}$ That is, the Court has divided into

courts); Kimel v. Fla. Bd. of Regents, 528 U.S. 62 (2000); Bd. of Trustees of the Univ. of Ala. v. Garrett, 531 U.S. 356 (2001).

19. Concerning Congress's Commerce Clause powers, see Garcia v. San Antonio Metropolitan Transit Authority, 469 U.S. 528 (1985) (holding that Congress has power under Commerce Clause to apply federal minimum wage and overtime provisions to state employees), overruling Nat'l League of Cities v. Usery, 426 U.S. 833 (1976); United States v. Lopez, 514 U.S. 549 (1995) (striking down for the first time since the New Deal a federal statute regulating private conduct-possession of a gun in a school zone-as beyond Congress's power to regulate interstate commerce); and United States $v$. Morrison, 529 U.S. 598 (2000) (holding in relevant part that Congress was without power under Commerce Clause to enact provision of Violence Against Woinen Act of 1994 (VAWA) that created a federal civil remedy for victims of gender-motivated violence).

Concerning the constitutional limits that the Tenth Amendment imposes on Congress's regulatory powers, see Garcia, 469 U.S. 528; New York v. United States, 505 U.S. 144 (1992) (holding that a federal statute requiring states to either regulate radioactive waste or take title to the waste constitutes compulsion and commandeering of the governmental eapacity of state governments, not encourageinent, and therefore is beyond Congress's regulatory power); and Printz $v$. United States, 521 U.S. 898 (1997) (holding that Congress may not "comandeer" local sheriffs by requiring them to perform background checks on would-be handgun purchasers in conformity with the provisions of the Brady Act).

Concerning Congress's powers under Section 5 of the Fourteenth Amendment to enforce the constitutional guarantees of Section 1, see City of Boerne v. Flores, 521 U.S. 507 (1997) (holdmg unconstitutional the Religious Freedom Restoration Act (RFRA), which sought to overrule the Court's interpretation of the Free Exercise Clause on the ground that Congress's power under Section 5 extends only to the creation of remedies for constitutional violations, not to alteration of substantive rights); Florida Prepaid, 527 U.S. 627 (holding provisions of Patent and Plant Variety Protection Remedy Clarifieation Act of 1992 abrogating states' sovereigu immunity unconstitutional as beyond Congress's powers under Section 5 of Fourteenth Amendment); College Savings Bank, 527 U.S. 666 (holding provisions of Trademark Remedy Clarification Act abrogating states' sovereigu immunity unconstitutional as beyond Congress's powers under Section 5); Kimel, 528 U.S. 62 (holding that Section 5 would not sustain effort by Congress to abrogate states' sovereigu immunity with regard to suits under Age Discrimination in Employment Act of 1967 (ADEA)); Morrison, 529 U.S. at 619-27 (holding in relevant part that Congress was without power under Section 5 to enact select provisions of VAWA that created a federal civil remedy for victims of gender-motivated violence); and Garrett, 531 U.S. 356 (holding that the Americans with Disabilities Act (ADA) does not constitute a valid exercise of Congress's Section 5 authority, and therefore states are immune from suit with respect to claims for money damages brought by private citizens under the ADA).

20. Not only did Seminole Tribe overrule Union Gas, but also College Savings Bank overruled Parden v. Terminal Railway, 377 U.S. 184 (1964), on the issue of whether a state validly waives its sovereign immunity from suit by continuing to act in interstate commerce after a federal statutory standard is established. Additionally, Garcia overruled National League of Cities, and National League of Cities itself ovemuled Maryland v. Wirtz, 392 U.S. 183 (1968) (upholding the 1966 extension of the Fair Labor Standards Act to state schools and hospitals). While Garcia itself has not been explicitly overruled by the present conservative majority, its influence has generally been declining (to say the least) on the question whether federalism questions require politieal solutions or judicial intervention. But see infra note 80 . As Vicki Jackson concludes:

These recent federalism decisions [i.e., Seminole Tribe, Lopez, and New York] are united by the diminished (in some cases invisible) role of Garcia v. San Antonio Metropolitan Transit Authority and its view that the interests of the states ean largely be safeguarded through the structures of federalisin themselves. In New York and in Seminole Tribe, the record of state participation in resolving an ongoing problem at a national level through legislation to which states as such significantly contributed is clear. There can be little doubt that the "safeguards of the federal structure" were in play there, if they ever can be said to be in play. That the 
stable and opposed camps, which we can denominate conservative and liberal. The conservative majority ${ }^{21}$ believes that the Constitution confers on the states a robust immunity from suit by private citizens, so that Congress's power to pierce that immunity is extremely limited. ${ }^{22}$ The liberal minority, ${ }^{23}$ on the other hand, maintains that the states' immunity exists only as a matter of federal common law, so that Congress enjoys ample authority to abrogate that immunity under any of its enumerated powers. ${ }^{24}$

In the event one of the conservative Justices steps down and Bush does not get the sort of Justice he wants on the issue of state sovereign immunity ${ }^{25}$ (similar to his father's experience with Justice Souter), ${ }^{26}$ the individual views of the remaining and new ${ }^{27}$ Justices on the question whether they may legitimately abandon stare decisis for no better reason than that a change in the Court's composition has empowered a new majority that thinks the precedent was wrongly decided will, of course, greatly influence whether Seminole Tribe meets the same fate as Union Gas. ${ }^{28}$ Less obvious,

Court largely ignored the relevance of these safeguards suggests that the influence of Garcia is, at best, waning.

Vicki C. Jackson, Seminole Tribe, The Eleventh Amendment, and the Potential Evisceration of Ex Parte Young, 72 N.Y.U. L. REv. 495, 541-42 (1997) (footnotes omitted). Similarly, Herbert Hovenkamp argues that in Lopez and Seminole, "activist Justices have struck down federal legislation on historically inaccurate constitutional grounds in an area, state-federal relations, where the political process has shown itself to be quite up to the task of allocating decisionmaking power." Herbert Hovenkamp, Judicial Restraint and Constitutional Federalism: The Supreme Court's Lopez and Seminole Tribc Decisions, 96 Colum. L. Rev. 2213, 2213 (1996). As Meltzer observes, "one may doubt how significant a policy this Court finds stare decisis to be." Meltzer, supra note 10, at 30 .

21. The members of the conservative majority are Chief Justice Rehnquist, Justicc O'Connor, Justice Scalia, Justice Kennedy, and Justice Thomas.

22. See supra note 18 .

23. The members of the liberal minority are Justice Stevens, Justice Souter, Justice Breyer, and Justice Ginsburg.

24. See Seminole, 517 U.S. at 100 (Souter, J., dissenting), and Alden, 527 U.S. at 760 (Souter, J., dissenting).

25. Alternatively, it is possible that Bush will serve only one term, during which time the five-tofour conservative majority in this area of thc law will persist, and the Democrat who wins the 2004 election will get the sort of Justice he wants on the issue of state sovereigu immunity when one of the members of the current conservative majority steps down.

26. Though Justice Souter was a life-long Republican at the time he joined the Court, he is widely regarded as one of its most liberal members. See, for example, his dissents in Seminole Tribe, 517 U.S. at 100, and Alden, 527 U.S. at 760.

27. Approximately a year ago, a Newsweek article contained a possible "sbort list" for Bush, which included Edith H. Jones, Frank Easterbrook, J. Harvie Wilkinson 111, Emilio M. Garza, and J. Michael Luttig. Stuart Taylor Jr., The Supreme Question, NewsweEk, July 10, 2000, at 18.

28. It is worth emphasizing that the relevant issue insofar as respect for stare decisis is concerned is not whether the Court should ever overrule one of its own precedents, since no defensible constitutional jurisprudence could possibly defend the obsolete Constitution that would soon result from such a judicial practice; rather, the crux of the matter is whether the mere fact that a new majority of the Court thinks that a particular issue before it was wrongly decided in the past is itself sufficient for making new law, even without taking into account other considerations-such as the Casey factors. See Planned Parenthood v. Casey, 505 U.S. 833, 854-55 (1992) (articulating the "prudential and pragmatic considerations designed to test the consistency of overruling a prior decision with the ideal of the rule of law, and to gauge the respective costs of reaffirming and overruling a prior case," 
however, is the collective-action problem that the Justices continually face when deciding whether to follow precedent concerning the constitutional status of state sovereign immunity. This problem persists even insofar as a nuniber of Justices would be willing to concede certain issues related to state sovereign immunity that they presently possess the power to decide differently on grounds of a principled respect for precedent, and that they would in fact decide differently were they presented with them as an original matter. In particular, the conservative and liberal wings of the Court can be analogized to the prisoners in the classic Prisoners' Dilemma game. This is because the two blocs within the Court were and are situated in a Prisoners' Dilemma with respect to the question whether they should adhere to previous decisions that determined whether Congress had the constitutional authority to abrogate the states' sovereign immunity from suit. The first purpose of this Comment is to clarify and corroborate this claim, and then to propose a possible long-term solution to the collective action problem that the Justices face.

More immediately, however, the second goal of this inquiry is to bring into focus a significant hiatus in the current legal debate over state sovereign immunity. Commentators who applaud Justice Stevens's refusal to be bound by precedent on this issue and his implicit vow to overrule Seminole Tribe as soon as he has the requisite five votes ${ }^{29}$ are not hard to find. ${ }^{30}$ Regardless of whether Justice Stevens and these commentators are ultimately correct on the merits, this Comment endeavors to point out certain significant, disturbing, long-tern consequences of the Court's continuing to pursue their line of reasoning by overturning precedent when and only because they have the votes. As the word 'continuing' in the previous sentence indicates, this is not at all a partisan issue. This Comment argues that the same nefarious consequences have obtained as a result of the current conservative majority's refusal to regard precedent as seriously as it should. ${ }^{31}$

Part 1 presents the definition and orthodox game theoretic interpretation of the Prisoners' Dilemma. Part II demonstrates how the Justices' views on the role of stare decisis in determining the present and future constitutionality of Congress's abrogation power determine a Prisoners' Dilemma. Part III proposes a potential resolution to the collective action

\footnotetext{
including: (1) whether the precedent at issue "has proven to be intolerable simply in defying practical workability"; (2) "whether related principles of law have so far developed as to have left the old rule no more than a remnant of abandoned doctrine"; (3) "whether facts have so changed, or come to be seen so differently, as to have robbed the old rule of significant application or justification"; and (4) whether the rule "is subject to a kind of reliance that would lend a special hardship to the consequences of overruling and add inequity to the cost of repudiation").

29. See supra note 1 .

30. See infra note 61 and accompanying text.

31. See infra Part II.
} 
problem in which the Justices are embroiled-in short, a mutual commitment to playing a different game than the one they have been playing - and also points out the highly contingent nature of this potential solution. The Comment concludes by cautioning both the most ardent defenders and the most virulent critics of Seminole Tribe that the present and future Justices' disrespect for precedent on the question it decided perpetuates a long-term trend of decision making that renders liberals and conservatives alike, both within the Court and outside it, worse off than they would be were the Justices to display greater respect for stare decisis in this area of the law.

\section{I \\ The Definition and Orthodox Game Theoretic Interpretation of the Prisoners' DILEMma}

\section{A. Technical Definition of the Prisoners' Dilemma}

Many of the more popular games of game theory ${ }^{32}$ come with a story attached. ${ }^{33}$ The Prisoners' Dilemma, the most famous of all these games, is no exception. ${ }^{34}$ The story is set in New York, or Chicago, or any other big city. There are two prisoners who the authorities believe to be jointly guilty of a major crime. Nevertheless, the prosecutor's office does not possess enough evidence to prove this allegation in court. What it can prove is that the prisoners jointly committed a minor crime. So the district attorney visits each prisoner separately in his cell and asks him whether or not he will confess. The district attorney informs each one that if both confess, he will prosecute them for the major crime, but he will recommend a reduced sentence, say, five years imprisonment instead of ten. If neither confesses, he will prosecute them for the minor crime, and each will receive two years imprisonment. Finally, if one confesses but the other does not, the former will receive lenient treatment for turning state's witness and be sentenced to one year in prison, while the latter will have the book thrown at him and get ten years.

The following game matrix (Table 1.1), which lists Prisoner 1's payoff first in each cell, summarizes the above information concerning each prisoner's two possible strategy choices and their associated consequences,

32. Two prominent economists and game theorists define game theory as

a bag of analytical tools designed to help us understand the phenomena that we observe when decision-makers interact. The basic assumptions that underlie the theory are that decisionmakers pursue well-defined exogenous objectives (they are rational) and take into account their knowledge or expectations of other decision-makers' behavior (they reason strategically).

Martin J. Osborne \& Ariel Rubinstein, A Course in Game Theory 1 (1994).

33. While such stories add humor and texture, their principal purpose is analytical-namely, to remind the analyst who gets which payoff in each situation.

34. The Rand scientists Drescher and Flood are credited with originally formulating the Prisoners' Dilemma in 1950. Albert Tucker, who gave the game its nickname, was the first to write about it. See 1 Ken Binmore, Game Theory and the Social Contract: Playtng Fair 102 (1994). 
given the other's choice of strategy. Note that the choice of confession constitutes noncooperation (NC) while nonconfession corresponds to cooperation $(\mathrm{C})$, because the relevant strategic issue is whether the prisoners will remain faithful to each other, not whether they will cooperate with the authorities.

TABLE 1.1

\begin{tabular}{|c|c|c|c|}
\hline & \multicolumn{3}{|c|}{ Prisoner 2} \\
\hline & & Don't Confess (C) & Confess (NC) \\
\hline \multirow[t]{2}{*}{ Prisoner 1} & Don't Confess (C) & 2,2 & 10,1 \\
\hline & Confess (NC) & 1,10 & 5,5 \\
\hline
\end{tabular}

Translating prison sentences into payoffs,${ }^{35}$ where a higher payoff is preferred to a lower payoff (for example, 10 years in prison $=1,5$ years $=$ 2,2 years $=3$, and 1 year $=4$ ), the following matrix results:

TABLE 1.2

Prisoner 2

Prisoner 1

\begin{tabular}{|c|c|c|}
\hline & Don't Confess (C) & Confess (NC) \\
\hline Don't Confess (C) & $\mathrm{X}=3, \mathrm{X}=3$ & $\mathrm{Z}=1, \mathrm{~W}=4$ \\
\hline Confess (NC) & $\mathrm{W}=4, \mathrm{Z}=1$ & $\mathrm{Y}=2, \mathrm{Y}=2$ \\
\hline
\end{tabular}

Putting aside the colorful details of the above story and generalizing from Table 1.2, the formal definition of the basic, symmetrical Prisoners' Dilemma requires that each player order the four different potential outcomes as follows. ${ }^{36}$ The most favorable outcome obtains for a player if he does not cooperate while the other player does (with associated payoff W). The second-best result for each player is mutual cooperation (with associated payoff $X$ ). Next is mutual noncooperation (with associated payoff $Y$ ). Finally, the worst outcome for each player results when he cooperates

35. The payoffs may be ordinal or cardinal. Ordinal payoffs, in contrast to cardinal payoffs, are payoffs that reveal only an order of preference; they do not reflect relative intensities of preference. Daniel M. Hausman \& Michael S. McPherson, Economics, Rationality, and Ethics, in THE Philosophy of Economics: AN ANThology 252, 257 (Daniel M. Hausman ed., 2d ed. 1994). Thus, from an ordinal perspective, it does not matter how much more an agent prefers one outcome to another; all that matters is the order of her preference. Insofar as the payoffs in Table 1.2 are ordinal, assigning a payoff of 1 to a punishment of 10 years in prison and a payoff of 4 to a punishment of 1 year in prison only means that each prisoner prefers 1 year to 10 years; it does not mean that he prefers it four times as much.

36. This Comment concerns itself with the basic, symmetrical Prisoners' Dilemma, which is deflned in the text. For more sophisticated characterizing conditions that are beyond the necessary complexity and scope of this inquiry, see Stephen T. Kuhn \& Serge Moresi, Pure and Utilitarian Prisoner's Dilemmas, 11 EcoN. \& PHIL. 333, 335-38 (1995). Kuhn and Moresi distinguish between pure and impure Prisoners' Dilemmas, and between utilitarian and nonutilitarian Prisoners' Dilemmas. A Prisoners' Dilemma is pure if mutual cooperation is Pareto efficient relative to the class of independent and correlated mixed strategies. See id. at 335-36; infra note 37 for a definition and discussion of Pareto efficiency. Using the notation in the text, a symmetrical Prisoners' Dilemma is pure if and only if $\mathrm{X}>1 / 2(\mathrm{~W}+\mathrm{Z})$. Kuhn \& Moresi, supra at 336-37. 
while the other player does not (with associated payoff $Z$ ). Thus, each player's preference ordering is $\mathrm{W}>\mathrm{X}>\mathrm{Y}>\mathrm{Z}$, where " $"$ " means "is preferred to." This preference ordering encompasses both the fact that noncooperation dominates cooperation for each player ( $\mathrm{W}>\mathrm{X}$ and $\mathrm{Y}>\mathrm{Z}$ ), and that mutual cooperation is Pareto superior to mutual noncooperation $(X>$ Y). ${ }^{37}$

\section{B. The Orthodox Interpretation of the Prisoners' Dilemma}

Game theorists analyze the Prisoners' Dilemma using the basic solution concepts of game theory, the most important of which are discussed in turn below.

\section{Strict Domination}

Assuming a player has two possible strategies, $A$ and $B, A$ strictly dominates $B$ insofar as the player is better off choosing $A$ over $B$ regardless of what strategy the other player(s) choose(s).$^{38}$ In the Prisoners' Dilemma, noncooperation strictly dominates cooperation for each player. To see this, consider Player 1's choice of strategy. If Player 2 chooses to cooperate, Player 1 does better by not cooperating and securing a payoff of 4 as opposed to 3. If Player 2 chooses not to cooperate, Player 1 does better by not cooperating and securing a payoff of 2 as opposed to 1 . Thus, regardless of which strategy Player 2 chooses, Player 1 is better off not cooperating. Because the game is structurally symmetrical, the same analysis holds for Player 2. Game theorists point to the fact that noncooperation strictly dominates cooperation in the Prisoners' Dilemma as unambiguously compelling the conclusion that noncooperation is the only rationally defensible strategy.

A Prisoners' Dilemma is utilitarian if mutual cooperation secures the players as much total utility as any other possible outcome. $I d$. at 337 . A symmetrical Prisoners' Dilemma is utilitarian if and only if $2 \mathrm{X}>\mathrm{W}+\mathrm{Z}$. Id. at 337-38. Thus, for symmetrical Prisoners' Dilemmas, the classes of pure and utilitarian Prisoners' Dilemmas coincide. For nonsymmetrical Prisoners' Dilemmas, which Kuhn and Moresi explicitly consider, the general result is that every utilitarian Prisoners' Dilemma is pure, but not all pure Prisoners' Dilemmas are utilitarian. Id. at 338. Note that both pure and utilitarian Prisoners' Dilemmas require cardinal utilities.

37. An outcome in a game or an allocation of resources in society is Pareto efficient or Pareto optimal if the only way to make one person better off is to make another person worse off. In contrast to cost-benefit analysis, another conception of efficiency in economics, Pareto efficiency does not allow losses. Cost-benefit efficiency allows losses insofar as the winners win more than the losers lose. A Pareto superior move in a game makes all players better off, so that the outcome from which the move takes place cannot be Pareto efficient. The outcome to which the move results may or may not be Pareto efficient relative to other feasible outcomes.

38. For a formal definition and discussion of strict domination, see OsBORNE \& RUBINSTEIN, supra note 32, at 59. For an introductory, more accessible treatment, see RoBERT COOTER \& THOMAS ULEN, LAw AND Economics 37 (3d ed. 2000). Domination arguments were first discussed in detail by Duncan Luce and Howard Raiffa in 1957. See OsBorne \& RuBINSTEIN, supra note 32, at 64 (citing Duncan Luce \& Howard Raiffa, Games and Decisions 108-09 (1957)). 


\section{Nash Equilibrium}

Additionally, mutual noncooperation constitutes the unique Nash equilibrium of the game, which is the most basic and commonly used solution concept in game theory. The Nash equilibrium is a profile of strategies in which no player has any incentive to change her strategy, given the strategies of the other players. A Nash equilibrium is thus stable in the sense that once it is achieved, none of the players have any incentive to deviate from it. ${ }^{39}$ This can be seen by underlining in Table 1.2 each player's best reply to a choice of strategy by the other player ${ }^{40}$ Each player's best reply is indicated in Table 1.3 immediately below.

\section{TABLE 1.3}

\begin{tabular}{|c|c|c|c|}
\hline \multirow{4}{*}{ Player 1} & \multicolumn{3}{|c|}{ Player 2} \\
\hline & & Cooperation (C) & Noncooperation (NC) \\
\hline & Cooperation (C) & 3,3 & $1, \underline{4}$ \\
\hline & $\begin{array}{c}\text { Noncooperation } \\
\text { (NC) }\end{array}$ & 4,1 & $\underline{2}, \underline{2}$ \\
\hline
\end{tabular}

Starting with Player 1, if Player 2 cooperates, Player 1's best reply is to not cooperate because $4>3$. If Player 2 does not cooperate, Player l's best reply is to not cooperate because $2>1$. Moving to Player 2, if Player 1 cooperates, Player 2's best reply is to not cooperate because $4>3$. If Player 1 does not cooperate, Player 2's best reply is to not cooperate because $2>1$. The only cell of Table 1.3 in which best replies for both Players 1 and 2 are present is the bottoin-right one-the one corresponding to the outcome that results when both players do not cooperate. Thus, inutual noncooperation constitutes the unique Nash equilibrium of this game. In the bottom-right cell, given the other player's choice of strategy, neither player has any incentive to deviate from his own strategy choice. That is what makes this profile of strategies an equilibrium. ${ }^{41}$

39. For a formal definition and discussion, see OSBORNE \& RUBINSTEIN, supra note 32, at 14-15. The Nash equilibrium is named after John F. Nash, who was the first to formalize the solution concept. See id. at 29 (citing John F. Nash, Equilibrium Points in N-Person Games, in ProceEdNGs of the National Academiy of Sciences of the United States of America 36, 48-49 (1950)). In 1994, Nash, John C. Harsanyi and Reinhard Selten were awarded the Nobel Prize in Economic Science "for their pioneering analysis of equilibria in the theory of non-cooperative games." The Nobel Prize Internet Archive at http://almaz.com/nobel/economics/1994b.html (last visited Feb. 19, 2001). The basic idea behind the Nash equilibrium goes back at least to Coumot. See OsBorne \& RUBinsteIn, supra note 32, at 29-30 (citing A.A. Cournot, Researches into the Mathematical Principles of THE THEORY OF WEALTH (Macmillan 1897) (1838)).

40. For a formal definition and discussion of best-reply or best-response functions, see OsBORNE \& RUBRINTEIN, supra note 32 , at 15 .

41. As if strict-domination and Nash-equilibrium arguments are not enough, it turns out that noncooperation also constitutes each player's unique maxmin strategy, which derives its name from the fact that a player uses it to maximize his minimum payoff. It is the most prudent, cautious, conservative strategy a player can choose, one that game theorists defend employing insofar as a player doubts the 


\section{Subgame Perfect Equilibrium}

The theory presented so far has been limited to interpreting the Prisoners' Dilemma as a strategic game, which is a model of a strategic interaction in which each player chooses his plan of action once and for all before the game begins, and all players' decisions are made simultaneously. That is, when choosing a plan of action, a player is not informed of the plan of action chosen by the other player(s) ${ }^{42}$

By contrast, the Prisoners' Dilemma presently confronting the two wings of the Court on the issue of stare decisis and state sovereign immunity is more appropriately modeled as an extensive game ${ }^{43}$ which specifies the possible orders of events: each player can consider his plan of action not only at the beginning of the game, but also whenever he must make a decision. ${ }^{44}$ In an extensive game, the solution concept of Nash equilibrium is unsatisfactory because it ignores the sequential structure of the decision problems in the game, thereby not distingnishing between equilibria that do and do not depend upon noncredible threats.

To see this, consider the following game in strategic form, which is taken from id. at 95-96:

TABLE 1.5

Player 2

other's rationality. Each player's maxmin strategy is evident from an examination of Table 1.4 immcdiately below.

TABLE 1.4

Player 2

\begin{tabular}{|c|c|c|c|}
\hline & Cooperation (C) & Noncooperation (NC) \\
\hline \multirow{3}{*}{ Player 1 } & Cooperation (C) & 3,3 & 1,4 \\
\hline Noncooperation (NC) & 4,1 & 2,2 \\
\hline
\end{tabular}

If Player 1 cooperates, the worst he can do is receive a payoff of 1 , which occurs if Player 2 does not cooperate. If Player 1 does not cooperate, the worst he can do is receive a payoff of 2 , which occurs if Player 2 does not cooperate. Since $2>1$, Player 1's most prudent, cautious choice of strategy is noncooperation. Because the game is structurally symmetrical, the same analysis holds for Player 2 .

For a formal definition and discussion of the maxmin strategy, see OSBORNE \& RUBINSTEIN, supra note 32, at 21-22. The idea of maxminimization dates back at least to the early eighteenth century. Id. at 30 (citing H.W. Kuhn, Preface to Waldegrave's Comments: Excerpt from Montmort's Letter to Nicholas Bernoulli, in Precursors in Mathematical Economics: An ANThology 3, 3-6 (W.J. Baumol \& S.M. Goldfeld eds., 1968)). John von Neumann first formalized maxminimization as a game theoretic solution concept in 1928. See id. at 30 (citing John von Neumann, On the Theory of Games of Strategy, in 4 Contributions to the Theory of Games 13 (A.W. Tucker \& R.D. Luce eds., Princeton 1959) (1928)).

42. See id. at 3 .

43. See infra Part II.B.

44. See Osborne \& Rubinstein, supra note 32, at 3, 89-90. The notion of an extensive game originated with von Neumann and Morgensteru. See id. at 114 (citing JoHN voN NEUMANN \& OsCaR Morgenstern, THEORY of GAMES AND ECONOMIC BeHAVIor (1944)). 
Player 1

\begin{tabular}{|c|c|c|}
\hline & $\mathrm{L}$ & $\mathrm{R}$ \\
\hline $\mathrm{A}$ & 0,0 & $\underline{2}, \underline{1}$ \\
\hline $\mathrm{B}$ & $\underline{1}, \underline{2}$ & $1, \underline{2}$ \\
\hline
\end{tabular}

As the underlined best replies indicate, $(\mathrm{A}, \mathrm{R})$ and $(\mathrm{B}, \mathrm{L})$ are the two Nash equilibria of the game. In extensive form, the game looks as follows:

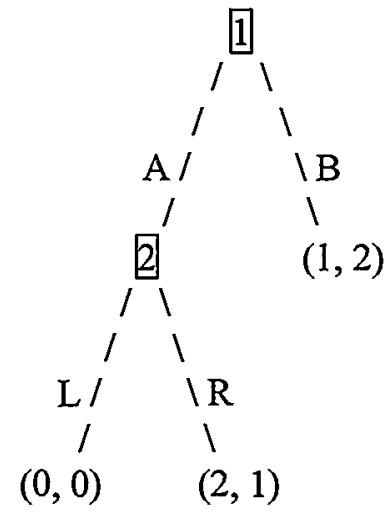

It is apparent from consideration of the above game tree that the Nash equilibrium $(B, L)$ lacks plausibility in the extensive-game context: If Player 1 were to choose A, then Player 2 optimizes by choosing R over L, thereby obtaining a payoff of 1 as opposed to 0 . The equilibrium $(B, L)$ is sustained by Player 2's threat to choose $L$ if player 1 chooses A. But this threat is not credible because, on the standard game theoretic account, he has no way of committing himself to the choice of $\mathrm{L}$ since he does better by choosing R. Thus, Player 1 has reason to be confident that, if she chooses $A$, then Player 2 will choose R. And because Player 1 prefers the Nash equilibrium outcome $(A, R)$ to the Nash equilibrium outcome $(B, L)$, she has an incentive to choose $A$.

Because the solution concept of Nash equilibrium does not account for the credibility of a threat that supports a particular equilibrium, it is necessary to define a notion of equilibrium that captures this crucial strategic consideration. Game theorists call the solution concept that does so a subgame perfect equilibrium. The notion of subgame perfect equilibrium eliminates Nash equilibria in which the players' threats are not credible by requiring that the action(s) prescribed by each player's equilibrium strategy be optimal, given the other players' strategies, within each subgame.$^{45}$ For example, in the game discussed above, the only subgame perfect equilib-

45. For a formal definition of subgame perfect equilibrium, see $i d$. at 97 . The notion of subgame perfect equilibrium is due to Reinhard Selten. Id. at 114 . 
rium is $(A, R)$ because only it is optimal within the subgame that begins when Player 2 has to choose a course of action.

The extensive-form representation of the Prisoners' Dilemma looks as follows:

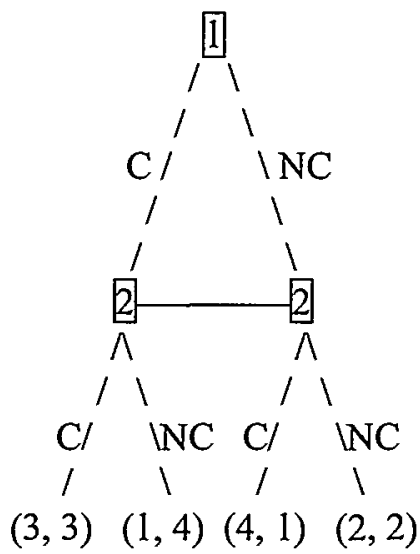

It is apparent from examination of the above game tree that the unique Nash equilibrium - mutual noncooperation-is also subgame perfect because the choice of noncooperation is optimal for Player 2 within the subgame that begins when he has to choose a course of action.

\section{The Dilemma}

All of these arguments-strict domination, unique Nash equilibrium, unique maxmin strategy, unique subgame perfect equilibrium-unambiguously support the game theorist's conclusion that noncooperation constitutes the only rationally defensible strategy choice in the Prisoners' Dilemma. Indeed, no generally accepted game theoretic solution concept argues in favor of cooperation. ${ }^{46}$ So where, then, lies the dilemma? lt resides in the fact that mutual cooperation is Pareto superior to mutual noncooperation, ${ }^{47}$ which is evident from the fact that both players would prefer moving from the bottom-right cell to the top-left cell in Tables 1.2 to 1.4. In the Prisoners' Dilemma, individual rationality in the conventional game theoretic sense results in collective irrationality.

The dilemma persists if the game is iterated a finite number of times because of an "unraveling" effect, also known as the endgame problem. ${ }^{48}$ The argument against noncooperation in any particular round lies in the threat that the other player will retaliate by not cooperating in the next round. However, this reasoning breaks down in the round known by both players to be the last, since retaliation is no longer possible. Thus, nonco-

46. But see infra note 71 .

47. For a definition of Pareto optimality, see supra note 37.

48. See COOTER \& ULEN, supra note 38, at 216-17. 
operation strictly dominates cooperation in the last round, and so-similar to the one-shot Prisoners' Dilemina analyzed above-rational choice theory prescribes mutual noncooperation as the rational strategy choice in the last round. Turning now to the next-to-last round, which is now in effect the last round, the same argument applies. This reasoning, known as backwards induction, ${ }^{49}$ leads game theorists to conclude that rational choice requires noncooperation in each round of a finitely repeated Prisoners' Dilemma, regardless of how long the series of iterations, as long as each player knows how many rounds the game will last. ${ }^{50}$

The only situation in which rational choice theory does not necessarily prescribe noncooperation in each round of the Prisoners' Dilemma is when the number of iterations is infinite, not known to the players, or determined probabilistically. ${ }^{51}$ In this situation, uncertainty prevents the backwards induction described above, and thus cooperation can be sustained as a Nash equilibrium in the repeated game. To support the cooperative outcome as a Nash equilibrium, each player must be deterred from deviating by the credible threat that he will be "punished" if he does so. Such punishment may take many forms, one of which entails each player's using a "trigger strategy":.52 any deviation by the other player causes him to carry out the punitive action forever. Note, however, that cooperation is not the umque Nash equilibrium solution to the Prisoners' Dilemma in the repeated context; rather, a very large number of Nash equilibrium solutions exist, many of which are noncooperative. ${ }^{53}$

\section{II \\ God Save This Pareto Inferior Court}

\section{A. The Recent History}

When confronted with precedent on the question of Congress's power to abrogate the states' sovereign immunity, the Justices have ignored

49. For a discussion of backwards induction, see OSBORNE \& RUBINSTEIN, supra note 32, at 99100.

50. Note that the endgame problem does not cause all finitely repcated games to unravel completely. The Prisoners' Dilemma is special because each player's minmax strategy-the strategy that minimizes the other player's maximum payoff and that a player chooses in order to punish the other player for defecting in the previous round-is the same as his strategy that forms part of the Nash equilibrium profile. $I d$. at 143 . Thus, a player camıt punish another player in round $n$ for defecting in round $n-1$ by making him worse off than he would be if the former played his equilibrium strategy in round $n$. This is not true of finite games in general. In general, cooperation can be sustained as a Nash equilibrium over a subset of the total number of rounds of a fimitely repeated game-that is, until the endgame problem sets in-whenever each player's use of his minmax strategy can cause the other player to end up with payoffs in rounds subsequent to the latter's choice of noncooperation that are lower than that player would receive in equilibrium when the game is played once. $I d$. at 155-60.

51. For a formal definition of an infinitely repeated game, see id. at 136-39.

52. See id. at 143 .

53. For a formal presentation of the Nash folk theorems that prove these propositions, see $i d$. at $143-46$. 
Justice Stewart's words of caution that changes in the Court's composition by themselves should not dictate changes in the Court's decisions. ${ }^{54}$ Indeed, Chief Justice Rehnquist's rather weak attempt in Seminole Tribe to rationalize overruling Union Gas notwithstanding, ${ }^{55}$ the former in fact overruled the latter for no more significant reason than a change in the Court's composition: Justices Brennan, White, Marshall, and Blackmun, all of whom voted in favor of Congress's power to abrogate the states' immunity in Union Gas, were replaced by Justices Souter, Ginsburg, Breyer, and Thomas, the last of whom voted against such congressional authority in Seminole Tribe.

Defenders of the Court's decision in Seminole Tribe might argue that the conservative majority was merely undoing the damage that the liberals had wrought in Union Gas, which, as the Chief Justice maintained in Seminole Tribe, "deviated sharply from our established federalism jurisprudence and essentially eviscerated our decision in Hans." ${ }^{.56}$ According to this argument for not respecting stare decisis, which is strikingly similar to Justice Stevens's in Kimel, ${ }^{57}$ the conservative Justices were justified in correcting the lack of respect for precedent that the liberals theinselves had shown in the past. This view maintains that, in light of their own "unclean hands," liberals within the Court cannot without hypocrisy find fault with the conservative majority's refusal to respect precedent in Seminole Tribe-especially given that the conservatives had a much better reason for so refusing in Seminole Tribe than did the liberals in Union Gas because the liberals moved first.

Two responses to this counter argument are in order. First, its limitations are revealed by a careful parsing of the Chief Justice's words-in particular, his use of the adverb "essentially" before "eviscerated." This qualifier implicitly concedes (at the same time that it obfuscates) that Union Gas was not inconsistent with any of the Court's previous holdings. This is because, prior to that case, the Court had never considered the

54. See supra note 3 and accompanying text.

55. The Chief Justice argued: (1) "The Court in Union Gas reached a result without an expressed rationale agreed upon by a majority of the Court"; (2) "Union Gas has created confusion among the lower courts that have sought to understand and apply the deeply fractured decision"; and (3) "[t]he plurality's rationale also deviated sharply from our established federalism jurisprudence and essentially eviscerated our decision in Hans." Seminole Tribe, 517 U.S. at 63-64. The Chief Justice's first justification ignores the fact that a majority did agree on the holding, if not the reasoning, in Union Gas. Thus, his first point is relevant to the issue of overruling precedent primarily insofar as it caused the second justification-namely, confusion in the lower courts. But this second reason also rings false since only the Eleventh Circuit-which had decided Seminole-read Union Gas as not permitting Congress to abrogate the state's immunity when acting under its enumerated powers. See Seminole Tribe v. Florida, 11 F.3d 1016 (11th Cir. 1994); see also Meltzer, supra note 10, at 29 (referring to the case law survey in In re Merchants Grain, 59 F.3d 630, 635-36 (7th Cir. 1995), vacated and remanded sub nom. Ohio Agric. Commodity Depositors Fund v. Mahern, 517 U.S. 1130 (1996)).

56. Seminole Tribe, 517 U.S. at 64.

57. See supra note 1 . 
question of congressional abrogation under Article I. Almost a century after adoption of the Eleventh Amendment, Hans v. Louisiana ${ }^{58}$ held that the Amendment and the principle for which it stands banned in-state as well as out-of-state citizens from suing a state. ${ }^{59}$ Whether Congress could overcome the states' immunity was not at issue in that case.

Second, and more importantly within the context of this inquiry, even if the defenders of Seminole Tribe are right and the above response somehow fails, this reality merely confirms this Comment's thesis that the Justices are embroiled in a long-term collective action problem on the issue of respecting precedent in the area of state sovereign immunity. This inquiry does not conceive itself as engaging in political or ideological advocacy. Rather, it is concerned with identifying a significant problem and exploring the virtues and limitations of alternative solutions, not with assigning blame on a partisan basis for having caused the problem in the first place. Conservatives may object to this Comment's beginning its "story" with Union Gas and not Hans, and the appropriate starting point is certainly open to reasonable disagreement. But neither conservatives nor liberals can reasonably nisist that no problem exists. The nature and relevance of the game theoretic analysis to follow renrains unchanged if the narrative is understood to have begun with Hans. What matters is not the starting point but the dynamics of the interaction over tine.

Insofar as the Seminole Tribe majority demonstrated unjustified disrespect towards Union Gas, liberals within and outside the Court might be quick to note that the decision in Seminole Tribe was more an act of political power and force than of judicial principle and reason. ${ }^{60}$ Nevertheless, one could justifiably judge these same liberals hypocritical if they now propose that a future liberal majority overrule Seminole Tribe. The lawreview literature certainly does not lack for commentators who so argue. Vicki Jackson, for example, writes that "Seminole Tribe, in short, should be abandoned-as quickly as possible."

58. 134 U.S. 1 (1890).

59. By its text, the Eleventh Amendment is applicable only to suits by out-of-state citizens. See U.S. CONST. amend. XI; see also infra notes 65,90 .

60. In addition to the above doctrinal analysis of the relationship between Union Gas and Hans, liberals also could point out that the first three Casey factors, and possibly even the fourth, argued against overruling Union Gas. See supra note 28.

61. Jackson, supra note 20, at 544; see also William A. Fletcher, The Eleventh Amendment: Unfinished Business, 75 NOTRE DAME L. REv. 843 (2000). Judge Fletcher writes:

As a number of commentators, including Professor Jackson, have argued, the task ... is to overrule Seminole Tribe. I believe that the decision is a mistake not only from the viewpoint of the four consistent dissenters on Eleventh Amendment issues. It is also at least a partial mistake from the viewpoint of the five Justices in the majority, and I hope that they will eventually recoguize the implications of their own previously expressed views of federalism and state sovereignty.

Id. at 853 (footnote omitted). See infra note 96 for Judge Fletcher's development of this point. 
In refuting the accusation of hypocrisy, liberals who agree with Jackson might point to Justice Stevens's opinion in Kimel, which was joined by Justices Souter, Ginsburg, and Breyer, in which he writes: "I remain convinced that Union Gas was correctly decided and that the decision of five Justices in Seminole Tribe to overrule that case was profoundly misguided. Despite my respect for stare decisis, I am unwilling

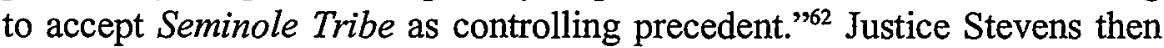
counts off seven reasons for his refusal to be bound by stare decisis on this issue, the last of which is that

by its own repeated overruling of earlier precedent, the majority has itself discounted the importance of stare decisis in this area of the law. The kind of judicial activism manifestcd in cases like Seminole Tribe, [Alden, and the two College Savings Bank Cases] represents such a radical departure from the proper role of this Court that it should be opposed whenever the opportunity arises. ${ }^{63}$

\section{B. The Prisoners' Dilemma Within the Court}

A standard game theoretic analysis validates Justice Stevens' reasoning: In light of the conservative wing's previous abandonment of precedent in Union Gas, the liberal bloc should do the same with Seminole Tribe when it has the requisite five votes in order to "punish" the other side for "defecting," thereby deterring similar defections in the future. Indeed, this logic becomes more compelling once one recoguizes that the majority's and minority's preferences over outcomes on the question whether to respect precedent concerning Congress's abrogation power determine a Prisoners' Dilemma.

To see this, consider the following extensive form representation of the game, in which the present conservative majority's payoffs are listed first in each parenthetical at the bottom, followed by the potential future liberal majority's. Each side may choose either to "cooperate" by following precedent or to "defect" by overruling precedent.

62. Kimel v. Fla. Bd. of Regents, 528 U.S. 62, 97 (2000) (Stevens, J., dissenting).

63. Id. at $98-99$. 


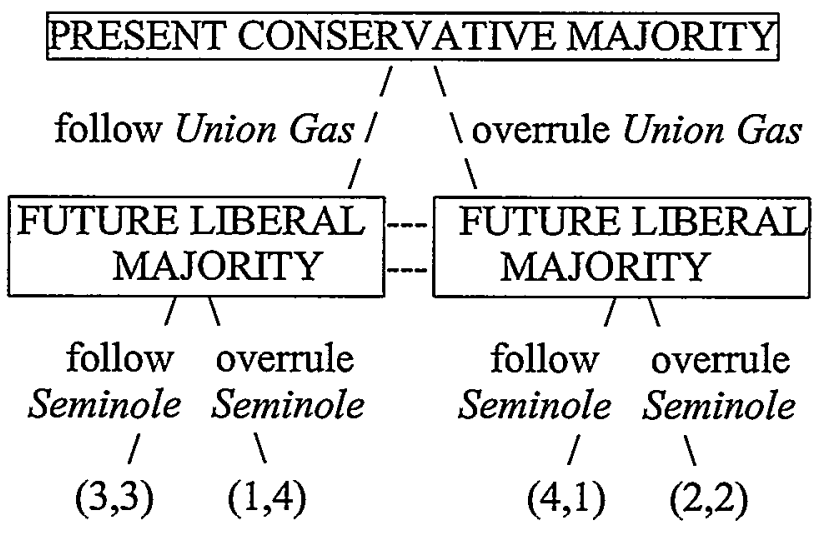

Applying the theory presented in Part I, the formal definition of the basic, symmetrical Prisoners' Dilemma requires that each wing of the Court order the four different potential outcomes as follows: A coalition obtains the best outcome for itself if it defects by overruling the other side's precedent while the other coalition cooperates by respecting stare decisis when it has the power to overrule the first side's precedent (with an associated payoff of 4). The second-best result for each side is mutual respect for stare decisis (with an associated payoff of 3). Next in lime is mutual overruling of precedent (with an associated payoff of 2). Finally, each coalition is worst off when it cooperates by respecting the other side's precedent when it has the opportunity to overrule it while the other coalition defects by overruling the first side's precedent when it has the power to do so (with an associated payoff of 1). Generalizing by letting $W=4, X=3, Y=2$, and $Z=1$, each coalition's preference ordering is $W>X>Y>Z$, where " $>$ " means "is preferred to." This preference ordering determines both that noncooperation dommates cooperation for each side ( $\mathrm{W}>\mathrm{X}$ and $\mathrm{Y}>\mathrm{Z}$ ), and that mutual cooperation is Pareto superior, or mutually preferred, to mutual noncooperation $(\mathrm{X}>\mathrm{Y}) .^{64}$

This ordering accurately characterizes both sides' preferences on whether to overrule or sustain Union Gas or Seminole Tribe. Each wing would most prefer to overrule the other side's precedent while the other side respects its precedent, and each least prefers the opposite scenario. At the same time, however, it is most reasonable to presume that both sides prefer mutual sustaining of precedent to mutual disrespect for stare decisis insofar as they have to choose between the two ex ante (that is, before cases are decided). This is so for two reasons. First, replicability, stability, and consistency in application are values that the ideal of the rule of law is

64. See Kuhn \& Moresi, supra note 36, at 334-35. 
intended to serve. ${ }^{65}$ Second, over the long-term, each wing of the Court arguably does better in terms of realizing its own understanding of what the Constitution requires by getting its way on fewer issues for a longer period than it does by getting its way on more issues for a shorter period, which is what happens when the Court engages in the sort of judicial flip-flopping that we have seen in its Eleventh Amendment jurisprudence.

As applied to the issue of state sovereign immunity, the dilemma after which the game is named resides in the unfortunate reality that each side prefers mutual sustaining of precedent to mutual disrespect for stare decisis, but insofar as the game is played once (which, in a sequential game, means that one side acts and then the other), it is structured such that it is in each side's self-interest to overrule the other's precedent regardless of what the other side does. As discussed in Part I, ${ }^{66}$ game theorists argue that the only way this common tragedy can rationally be avoided-namely, by sustaining mutual respect for stare decisis as an equilibrium-is for each side to play the game an infinite or indefinite number of times-which the Supreme Court does-and to enforce mutual respect for precedent by punishing the other side's defections with defections of its own. Thus, the legal relevance of the foregoing game theoretic analysis lies in its prescription that, even if the liberal wing of the Court is concerned only about long-run respect for stare decisis and not substantive outcomes on the issue of congressional abrogation of state sovereigu immunity, it should overrule Seminole Tribe if and when it has the requisite five votes in order to deter future abandonment of precedent by the other side. This is just a legal application of the general game theoretic principle that the only rational way to enforce long-term cooperation in an indefinitely repeated Prisoners' Dilemma is to punish short-run, self-interested deviations from the cooperative norm.

65. See Post, supra text accompanying notes 11-12. The Eleventh Amendment is in as much need of the stabilizing influence of stare decisis as the clauses of the Fourteenth Amendment not so much because of its "vague textual referents" as because, as the conservative majority readily admits, the constitutional doctrine of state sovereign immunity is much more expansive than any plausible interpretation of the text of the Eleventh Amendment itself can justify. See Seminole Tribe v. Florida, 517 U.S. at 54 ("Although the text of the Amendment would appear to restrict only the Article III diversity jurisdiction of the federal courts, "we have understood the Eleventh Amendment to stand not so much for what it says, but for the presupposition ... which it conflrms." (quoting Blatchford $v$. Native Vill., 501 U.S. 775, 779 (1991)). "That presupposition, first observed over a century ago in Hans v. Louisiana, 134 U.S. 1 (1890), has two parts: first, that each State is a sovereign entity in our federal system; and second, that '[i]t is inherent in the nature of sovereignty not to be amenable to the suit of an individual without its consent."' Id. at 54 (cmphasis omitted) (quoting THE FEDERALIST No. 81 (Alexander Hamilton)).

66. See supra text accompanying note 53 . 
III

A Potential Solution to the Prisoners' Dilemma within the Court: A Mutual Commtment to Respecting Precedent

\section{A. The Legal Limitations of the Standard Game Theoretic Approach}

The standard game theoretic approach to the problem of stare decisis and state sovereign immunity discussed above arguably contams too much economic abstraction and not nearly enough legal contextuality. In particular, when the Court overrules one of its own precedents, it does much more than "punish" the Justices on the other side for deviating from stare decisis in the past; more importantly, it uses its constitutional power to change the fundamental law of the land, in accordance with which citizens orgamize their everyday affairs, and as a long-term result of which its legitimacy as a legal institution either is secured or slowly begins to erode. That is, there can be significant reliance interests that are disturbed, as well as insidious, long-run, negative effects on the Court's institutional legitimacy, when the Justices repeatedly overrule their own precedents for reasons that do not appear to take sufficient account of the independent value of stare decisis and that turn on a mere change in the Court's personnel that empowers a new majority to make new law. The game theoretic analysis delineated above does not take into account these pressing parameters. It very arguably would constitute a betrayal of a Justice's judicial duty if she were to ignore these legal considerations and single-mindedly pursue a "punishment strategy" in the name of respect for stare decisis. ${ }^{67}$

In order to formulate a way for the Justices to secure respect for stare decisis over the long term while at the same time remaining sufficiently sensitive to the other legal considerations discussed immediately above, the next section will offer a proposed solution to the collective action problem the Justices face on the problem of state sovereigu immunity.

\section{B. The Games Justices Play}

The Prisoners' Dilemina in which the Justices are embroiled may appropriately be called the "Merits Game" because each side's preferences over outcoines are driven by its views concerning whether the issue of congressional abrogation of state sovereign immunity in Seminole Tribe

67. Of course, the liberals within and outside the Court-including Justice Stevens-do not want Seminole Tribe to be overnuled primarily in order to "punish" the present conservative majority for its previous refusal to follow Union Gas in Seminole Tribe. Rather, they want it to be overruled primarily because they believe that the Court's decision in that case was wrong-indeed, very wrong-and because they believe that there is a great deal at stake in terms of restoring Congress's constitutional authority to provide private damages actions against states who willfully violate valid federal law. Thus, whereas the game theoretic analysis conducted in Part ll confirms the liberal wing's judgment that Seminole Tribe should be overruled, its rationale for so concluding validates only that portion of Justice Stevens's statement in Kimel quoted at the beginning of this Comment and reiterated in Part II.A. See supra notes 1, 62-63. 
was correctly decided on the merits as an original matter ${ }^{68}$ The standard form representation of this game ${ }^{69}$ is as follows:

TABLe 3.1: The Merits Game

Player 2: The Conservative Majority

\begin{tabular}{l|c|c|c|}
\cline { 2 - 4 } & & Respect precedent & Overturn precedent \\
\cline { 2 - 4 } $\begin{array}{c}\text { Player 1: } \\
\text { The Liberal } \\
\text { Majority }\end{array}$ & Respect precedent & 3,3 & $1, \underline{4}$ \\
\cline { 2 - 4 } & Overturn precedent & $\underline{4}, 1$ & $\underline{2}, \underline{2}$ \\
\cline { 2 - 4 } & & &
\end{tabular}

The standard conclusions of game theory developed in Part I follow. As the underlined best replies indicate ${ }^{70}$ mutual overturning of precedent constitutes each side's strictly dominant, unique Nash equilibrium strategy. ${ }^{71}$

68. See supra Part II.B for an explanation of why these preference orderings accurately characterize the Justices' views on following precedent with regard to state sovereign immunity.

69. This section uses the strategic form representation of games that are more accurately represented in extensive form, see supra Part I.B.3, for two reasons. First, all of the Nash equilibria are subgame perfect (since none of them depend upon one side's making non-credible threats), so the strategic form representation is not misleading. Second, it is much easier to perceive what the Nash equilibria are in the strategic form representations of games.

70. See supra Part I.B to review how one determines best replies.

71. Note that this game theoretic analysis is not uncontroversial. As part of his critique of the behavioral foundations of economic theory, Amartya Sen has defended the rationality of cooperation even in a one-shot Prisoners' Dilemma. Sen was awarded the Nobel Prize in Economic Science in 1998 for "several key contributions to the research on fundamental problems in welfare economics." Press Release, The Royal Swedish Academy of Sciences, The Bank of Sweden Prize in Economic Sciences in Memory of Alfred Nobel 1998 (Oct. 14, 1998), at http:/www.nobel.se/laureates/1998/press.html.

For Sen's interpretation of the Prisoners' Dilemma in the context of his more general critique of the behavioral foundations of economic theory, see AMARTYA SEN, ON ETHICS AND EconOMICs 1522, 80-88 (1987); Amartya Sen, Behaviour and the Concept of Preference, 40 EconomiCA 24I, 253-58 (1973); Amartya Sen, Choice, Orderings and Morality, in Practical Reason 54, 6I-62 (Stephan Kömer ed., 1974); Amartya Sen, Rational Fools: A Critique of the Behavioral Foundations of Economic Theory, 6 PHIL. \& PUB. AfF. 317, 341 (I977). For an explanation and legal application of Sen's critique of the behavioral foundations of economic theory, see Neil S. Siegel, Comment, Sen and the Hart of Jurisprudence: A Critique of the Economic Analysis of Judicial Behavior, 87 CALIF. L. REV. 1581 (1999) (arguing that economic models provide an indefensible account of judicial behavior because the assumption of self-interest maximization is readily falsified in the judicial context insofar as judges behave legitimately, and in any event, is incompatible with a jurisprudence that rccognizes basic rule-of-law values).

This Comment does not draw from Sen's work in proposing a solution to the Prisoners' Dilemma within the Court on the subject of state sovereign immunity because the potential conflict between an agent's preference and her welfare that his critique of economic theory posits is not relevant in this context. From the perspective of economic theory, at stake here is not a conflict between a Justice's preference and her welfare, but rather between two types of preferences that a Justice may possess-her desire to decide a case on the merits the way she believes is correct and her desire to respect prccedent.

For an analysis of the jurisprudential problems with economic theory's conceptualization of these grounds of judicial decision making as "preferences," see Siegel, supra. The way to avoid these difficulties is to conceive of judges as rendering judgments as to what the law is based on legal doctrine, not as expressing their preferences as to what the law should be. See Lewis A. Komhauser \& Lawrence G. Sager, Unpacking the Court, 96 YALE L.J. 82, 88-89 (1986). Within the context of this inquiry, this means conceiving the numbers in the game matrices as ordering the Justices' judgments as 
The Justices play this game repeatedly and indefinitely. As we have seen, ${ }^{72}$ orthodox game theory argues that mutual respect for precedent can be sustained as a Nash equilibrium only if each player employs a punishment strategy. In light of the costs of a punishment strategy to the citizenry's reasonable expectations and the Court's legitimacy, ${ }^{73}$ this Comment proposes that the Justices can solve the collective action problem they face by making a mutual commitment to follow precedent. They can do so by acting as if they most prefer the outcome in which both wings of the Court demonstrate respect for stare decisis, thereby playing a different game than the one they have been playing. This Comment will call it the "Rule-ofLaw Game," which is represented in strategic form as follows:

TABle 3.2: The Rule-of-LAw Game

Player 2: The Conservative Majority

\begin{tabular}{c|c|c|c|}
\cline { 2 - 4 } Player 1: & & Respect precedent & Overturn precedent \\
\cline { 2 - 4 } The Liberal & Respect precedent & $\underline{4}, \underline{4}$ & 1,2 \\
\cline { 2 - 4 } Majority & Overturn precedent & 2,1 & $\underline{3}, \underline{3}$ \\
\cline { 2 - 4 } & &
\end{tabular}

As the underlined best replies indicate, neither player has a dominant strategy, and there are two Nash equilibria: mutual overturning of precedent and mutual respect for precedent.

The crucial feature of the Rule-of-Law Game is that both wings of the Court most prefer the cooperative outcome. Table 3.2 reflects the author's view of how a Justice concerned about maintenance of rule-of-law values should order the other three possible outcomes: mutual disrespect for precedent is superior to one side's being a sucker, and each side would least prefer to be the sucker. Nevertheless, reasonable disagreement over the proper ordering of these other three outcomes under rule-of-law criteria is possible. The important point to keep in mind is that regardless of how each side orders the other three outcomes, cooperation is sustainable as a Nash equilibrium, and so is economically rational.

The following additional two variants of the Rule-of-Law Game, with best replies underlined, confirm this fact.

to what the law requires of them, whether with respect to following precedent or expressing their views of the merits of particular cases, not as ordering their personal, subjective preferences concerning what they would like the law to be. The rcalisin of this view of judicial behavior, especially in the context of the Court's federalism revolution, is an entirely different question. See infra Part IIL.D-F.

72. See supra text accompanying notes 51-53.

73. See supra Part III.A. 
Table 3.3: The Rule-of-Law Game-Variant \#1

Player 2: The Conservative Majority

\begin{tabular}{c|c|c|c|}
\cline { 2 - 4 } & & Respect precedent & Overturn precedent \\
\cline { 2 - 4 } $\begin{array}{c}\text { Player 1: } \\
\text { The Liberal } \\
\text { Majority }\end{array}$ & Respect precedent & $\underline{4}, \underline{4}$ & 1,3 \\
\cline { 2 - 4 } & Overturn precedent & 3,1 & $\underline{2}, \underline{2}$ \\
\cline { 2 - 4 } & & \multicolumn{2}{|c}{}
\end{tabular}

Table 3.4: The Rule-of-Law Game-Variant \#2

Player 2: The Conservative Majority

\begin{tabular}{l|c|c|c|}
\cline { 2 - 4 } & & Respect precedent & Overturn precedent \\
\cline { 2 - 4 } $\begin{array}{c}\text { Player 1: } \\
\text { The Liberal } \\
\text { Majority }\end{array}$ & Respect precedent & $\underline{4}, \underline{4}$ & $\underline{2}, 3$ \\
\cline { 2 - 4 } & Overturn precedent & $3, \underline{2}$ & 1,1 \\
\cline { 2 - 4 } & &
\end{tabular}

In Table 3.3, each wing of the Court prefers being the exploiter to being exploited, and also prefers mutual overturning of precedent to one side's being a sucker. In Table 3.4, each bloc also prefers being the exploiter to being exploited, but now prefers being exploited to mutual overturning of precedent. In either case, mutual respect for precedent is a Nash equilibrium because, given that one side respects precedent, it is a best reply for the other to do so as well.

These two versions assume that each side prefers being the exploiter to being exploited. But mutual cooperation remains a Nash equilibrium even if this assumption is lifted.

Table 3.5: The Rule-of-Law Game-Variant \#3

Player 2: The Conservative Majority

\begin{tabular}{l|l|c|c|}
\cline { 2 - 3 } Player 1: & Respect precedent & Overturn precedent \\
\cline { 2 - 4 } $\begin{array}{c}\text { The Liberal } \\
\text { Majority }\end{array}$ & Respect precedent & $\underline{4}, \underline{4}$ & $\underline{3}, 2$ \\
\cline { 2 - 4 } & Overturn precedent & $2, \underline{3}$ & 1,1 \\
\cline { 2 - 4 } & &
\end{tabular}

TABle 3.6: The Rule-of-LAW GAME-Variant \#4 Player 2: The Conservative Majority

\begin{tabular}{c|c|c|c|}
\cline { 2 - 4 } & & Respect precedent & Overturn precedent \\
\cline { 2 - 4 } $\begin{array}{c}\text { Player 1: } \\
\text { The Liberal } \\
\text { Majority }\end{array}$ & Respect precedent & $\underline{4}, \underline{4}$ & $\underline{3}, 1$ \\
\cline { 2 - 4 } & Overturn precedent & $1, \underline{3}$ & 2,2 \\
\cline { 2 - 4 } & &
\end{tabular}


Table 3.7: The Rule-of-Law Game-Variant \#5

Player 2: The Conservative Majority

\begin{tabular}{l|c|c|c|}
\multirow{4}{*}{\begin{tabular}{c} 
Player 1: \\
The Liberal \\
\cline { 2 - 4 } Majority
\end{tabular}} & Respect precedent & Overturn precedent \\
\cline { 2 - 4 } & Respect precedent & $\underline{4}, \underline{4}$ & 2,1 \\
\cline { 2 - 4 } & Overturn precedent & 1,2 & $\underline{3}, \underline{3}$ \\
\cline { 2 - 4 } & &
\end{tabular}

These three matrices reflect every possible ordering of those outcomes in which at least one wing of the Court overturns precedent, on the assumption that each side would rather be the sucker than the exploiter. In all of them, mutual respect for precedent is a Nash equilibrium because each bloc does best for itself by respecting precedent, given that the other side is doing the same. Thus, under every possible permutation of the rule-of-law game, mutual cooperation is a Nash equilibrium.

What this analysis has demonstrated is that, if both wings of the Court commit themselves to respecting stare decisis by playing the Rule-of-Law Game instead of the Merits Game, mutual respect for precedent-the Pareto efficient outcoine in the Merits Game-is sustainable as an equilibrium. Thus, one can defend each side's respecting the other's precedent as economically rational, so that the tradeoff between efficiency and rationality that is present in the Prisoners' Dilemma, or the Merits Game, is resolved.

The crucial point of the foregoing game theoretic analysis is not that the Justices should prefer the Rule-of-Law Game to the Merits Game simply because the Nash equilibrium in the one-shot version of the former is Pareto efficient. This observation constitutes a non-argument for Justices whose values are reflected in the Merits Game since it amounts to the wholly uncompelling suggestion that such Justices ought to possess ruleof-law values merely because they can maximally satisfy them. Rather, the point is that, if the Justices were to behave as if they possessed rule-of-law preferences by playing the Rule-of-Law Game instead of the Merits Game, then all of them would do better in terms of satisfying their merits preferences than they have been doing by playing the Merits Game itself. This is a strategic consideration that ought to matter greatly to a merits-oriented Justice. Thus, though in the short run there almost always exists a trade-off between a judge's getting the merits right and her respecting the independent value of stare decisis, and though the foregoing game theoretic analysis does not theorize this trade-off at all, this Comment suggests that, at least within the context of state sovereign immumity and stare decisis, the strategic situation within the Court is such that the Justices would more fully realize their views of the inerits over the long run by paying inore-not less-respect for precedent. 


\section{Applying this Comment's Solution to State Sovereign Immunity and Stare Decisis}

In the judicial context of state sovereign immunity and stare decisis, the foregoing analysis demonstrates that the Justices can mutually commit themselves to the practice of stare decisis over the long run without the need to resort to a punishment strategy-which, as we have seen, ${ }^{74}$ game theorists argue constitutes the only rational means by which the players can achieve cooperation as an equilibrium solution in an indefinitely repeated Prisoners' Dilemma. By committing themselves to playing a different game than the one they have been playing, the Justices can eschew punishment strategies, thereby reconciling their displaying adequate respect for precedent with their paying due regard to other, equally important legal considerations - namely, the reliance interests to which legal rules give rise, and the Court's own long-term institutional legitimacy. ${ }^{75}$

Nevertheless, the solution this Comment has proposed requires a mutual commitment: Both wings of the Court must be prepared to forego playing the Merits Game in the interest of the Pareto superior equilibrium outcome they can obtain if they play the Rule-of-Law Game. If only one side is prepared to commit, this Comment's prescription offers no solution at all. After all, it makes little sense for one wing of the Court to be a "sucker" by continually cooperating in a process that makes its Justices systematically worse off because the other side refuses to reciprocate.

A simple game theoretic analysis confirms this reasoning. As an example, consider the situation in which the liberal wing of the Court has Rule-of-Law Game preferences while the conservative wing has those of the Merits Game. One may call this scenario the Liberals-as-Suckers Game. The payoff matrix, with best replies underlined, looks as follows:

TABLE 3.8: The Liberals-As-Suckers GaME

Player 2: The Conservative Majority

\begin{tabular}{l|c|c|c|} 
& & Respect precedent & Overturn precedent \\
\cline { 2 - 4 } $\begin{array}{l}\text { Player 1: } \\
\text { The Liberal } \\
\text { Majority }\end{array}$ & Respect precedent & $\underline{4}, 3$ & $1, \underline{4}$ \\
\cline { 2 - 4 } & Overturn precedent & 2,1 & $\underline{3}, \underline{2}$ \\
\cline { 2 - 4 } & &
\end{tabular}

Now one cannot defend respect for conservative precedents by the Liberal wing as economically rational because respecting precedent constitutes neither a strictly dominant strategy nor a Nash equilibrium strategy. ${ }^{76}$ As the underlined best replies indicate, mutual disrespect for stare decisis constitutes the unique Nash equilibrium of this game. And even though one could argue that respecting precedent constitutes the liberal Justices'

\footnotetext{
74. See supra text accompanying notes 51-53.

75. See supra Part IIl.A.

76. See supra Part 1.B.1 for a discussion of strict domination.
} 
maxmin strategy, ${ }^{77}$ the maxmin solution concept is not compelling in this strategic context since overturning precedent constitutes the conservative Justices' strictly dominant strategy, and there exists no reason to doubt their rationality.

On the question of whether the Justices should follow precedent concerning Congress's power to abrogate the states' immunity from suit, then, this Cominent's proposed solution to the collective action problem the Justices face is fundamentally contingent. It will work only if both wings of the Court show a greater respect for stare decisis than historically has been the case in the area of federalism in general and state sovereign immunity in particular. ${ }^{78}$ Insofar as this obtains, the fact that the present conservative majority lost its normative bearings in Union Gas should not dissuade a liberal majority that may einerge in the future from leading by example and paying proper attention to stare decisis in determining the constitutional validity of Seminole Tribe. If this is not the case, however, then the dilemina will continue unresolved. Putting aside the normative debate concerning the extent to which judges should respect the doctrine of stare decisis, as a positive, analytical matter, the perpetuation of this dilemma renders all of the Justices worse off given their ex ante preferences for following precedent with respect to the issue of congressional abrogation of state sovereign immunity.

\section{A Potentially Devastating Response}

Political liberals ${ }^{79}$ who care about the constitutional status of the states' immunity may be inclined to respond to the above observations and prescription—and, indeed, to this Comment's entire project-in something like the following fashion:

The present conservative majority is content to ignore stare decisis without compunction as it overturns every precedent which really matters that stands in the way of its realizing its robust vision of federalisin in general and state sovereign immunity in particular. With the right wing of the Court acting in this fashion, why should we behave any differently when we finally regain a majority? In the face of such outrageous behavior by the other side, are you seriously proposing that we surrender, and surrender, and surrender ...?

The strategic environment in which the Justices currently find themselves with respect to the issue of stare decisis and state

77. See supra note 41 for an explanation of the maxmin solution concept.

78. See supra note 20.

79. Note that there is nothing inherently politically liberal about the narrative that follows. The text refers to it as an anticipated "liberal" reaction because of the possible future scenario it positsnamely, a situation in which a new liberal majority has to decide what to do with Seminole Tribe and its progeny. 
sovereign immunity may be properly characterized as an extensiveform Prisoners' Dilemma, but what does that formalization add to the resolution of what a new liberal majority should do with Seminole Tribe? How does it help instruct the liberal Justices in how to behave? Certainly your proposed solution is of no help because, if the liberals were to gain a majority on the Court sometime soon, they then would be faced with precisely the situation that your solution cannot effectively address-namely, one in which they would be alone in respecting stare decisis insofar as they practiced a principled respect for precedent, so that, in short, they would be acting like the "suckers" that game theorists lament.

Moreover, when the conservatives on the Court find themselves in the minority and they begin to talk about the need to respect precedent, this would not constitute an indication of a sincere change of heart on their part that the liberals would be wise to count on in the future. On the contrary, it might be nothing more than a specious ploy that reflected the changing balance of power within the Court. When in the inajority, the conservative Justices vote to overturn liberal precedents; when in the minority, they talk about the value of preserving their own ....

This narrative, potentially devastating in its inplications for this inquiry, could be continued, but the general contours of its concerns are clear enough.

Though there is inore than a grain of truth in this narrative, as this Part already has analytically validated, one can nnake a number of responses that show how liberals overstate their case by reacting in this way, thereby underestimating the potential workability of this Comment's solution to the Prisoners' Dilemma in the judicial context of stare decisis and state sovereign immunity.

First, it is simply not true that the "present conservative majority is content to ignore stare decisis without compunction as it overturns every precedent which really inatters that stands in the way of its robust vision of federalisin in general and state sovereign immunity in particular." This characterization of the Court's behavior is excessive; as a consequence, it fails to capture the reality of the situation, which is less clear and more textured than this portrayal would suggest. Respect for stare decisis is always a matter of degree. To date, this Court has not overruled Garcia ${ }^{80}$ or

80. See supra note 19. On the other hand, the influence-if not the holding-of Garcia is clearly waning. See supra note 78. Additionally, it is not clear how much is even left of Garcia's holding after New York and Printz. See supra note 19. And yet reports of Garcia's death may be greatly exaggerated in light of the Court's surprising, unanimous, recent decision in Reno v. Condon, 528 U.S. 141 (2000), holding that the Driver's Privacy Protection Act (DPPA), which restricts the ability of states to disclose a driver's personal information without the driver's consent, is a proper exercise of Congress's authority to regulate interstate commerce under the Commerce Clause, and does not violate the principles of federalism contained in the Tenth Amendment. 
South Dakota v. Dole. ${ }^{81}$ In other areas of constitutional law, the Court did not overrule Roe v. Wade $e^{82}$ when it had the votes to do so, and most recently, it reaffirmed Miranda $v$. Arizona $a^{83}$ in the face of a direct constitutional challenge in a very strongly worded opinion by the Chief Justice himself. Thus, it is not as if stare decisis is of no value to this Court. ${ }^{34}$ This is reassuring in itself, as well as in light of the possibility that learning may take place at some point in the near future.

Though the Justices are largely set in their ways in their individual approaches to constitutional decision making, it is possible that at least one of the members of the present conservative majority may experience a change of heart on the issue of following precedent. On the other hand, the present conservative Justices may be well aware of what is at stake, but may not care very much about fidelity to precedent since they have had a majority for so long. Because "what goes around, comes around," as the saying goes, a future liberal majority's leading by example constitutes a high-risk, high-reward strategy. In any event, perhaps this Comment's formalization of the strategic situation within the Court and its offering

31. 483 U.S. 203 (1987) (assuming but not deciding that the Twenty-First Amendment would bar Congress from enacting a national minimum drinking age, holding that Congress may condition some percentage of federal highway funds on a recipient state's adopting a minimum drinking age). Given that the Twenty-First Amendment limits congressional action that would otherwise fall within the commerce power, it closely resembles the Court's interpretation of the Eleventh Amendment in this respect. This tight legal correspondence argues in favor of the constitutionality of Congress's use of its spending power in order to exact waivers of immunity from the states.

On the other hand, Dole intimated in dictum that there were limits on Congress's use of the spending power, stating that "our cases have suggested (without significant elaboration) that conditions on federal grants might be illegitimate if they are unrelated 'to the federal interest in particular national projects or programs." Id. at 207-08 (quoting Massachusetts v. United States, 435 U.S. 444, 461 (1978) (plurality opinion)). The Court could seize on and operationalize this notion as a way of limiting aggressive congressional use of the spending power to get around Seminole Tribe and its progeny.

Additionally, what the Court in Dole characterized as a condition or temptation it could readily portray as coercion in many statutory contexts. This reality is significant in light of the fact that the conservative majority has repeatedly demonstrated its willingness to revisit established constitutional doctrines to preserve its robust doctrine of state sovereigu immunity. In this regard, Fallon, Meltzer, and Shapiro forebodingly ask: "Given the majority's apparent willingness to chip away at other established constitutional doctrines in order to protect its vision of untrammeled state sovereign immunity, is the broad authority recognized in Dole to condition financial grants on state waiver a technique that may be narrowed or eliminated?" RICHARD H. FALLON, JR. ET AL., HART AND Wechsler's The Federal CourTs and tHe Federal System 111 (4th ed. Supp. 1999) (citations omitted). It may not be unduly pessimistic - but rather simply realistic-to conclude that the answer to this question is a resounding "yes."

82. 410 U.S. 113 (1973); see Planned Parenthood v. Casey, 505 U.S. 833 (1992); see also supra notes 2,28 and accompanying text.

83. 384 U.S. 436 (1966); see Dickerson v. United States, 530 U.S. 428 (2000).

84. But see Larry D. Kramer, No Surprise. It's an Activist Court., N.Y. TimES, Dec. 12, 2000, at A33 (arguing that "[t]he Rehnquist Court has been using law to reshape politics for at least a decade"; that "conservative judicial activism is the order of the day"; that "[ $t]$ he court cast aside nearly 70 years of precedent in the area of federalism"; and, in light of the fact that the Court "reached out aggressively to solve the nation's election problem," that "[j]udicial prerogative, it seems, not states' rights, has been at the heart of the Rehnquist Court's docket"). 
what may be the only possible solution to the collective action problem the Justices face may contribute to the scholarly dialog concerning, and the Court's appreciation of, the importance of stare decisis.

Finally, future changes in the Court's personnel will also include conservative jurists, some of whom may take precedent more seriously than the members of the present conservative majority currently do. New conservative justices may be even more inclined to take precedent seriously if the liberal majority that may exist when they join the Court respects the principle of stare decisis. Thus, greater fidelity to stare decisis does not depend exclusively upon one of the current conservative Justices experiencing a change of heart. ${ }^{85}$

\section{E. Where We Go from Here}

If the conservative Justices who now sit on the Court do not come to respect precedent more than they currently do, and if they are not replaced over time by conservative jurists whose commitment to stare decisis is stronger, then there can be no adequate response to the challenge posed by the liberal narrative developed above. One party to a collective action problem cannot solve the problem on its own. Moreover, the country and the Constitution would be worse off if the members of a future liberal majority made "suckers" out of themselves by rigorously adhering to precedent regardless of the fact that the right wing of the Court was unwilling to do the same. Such behavior would result in a strong conservative bias in constitutional law over the long term as liberal majorities respected conservative precedents while conservative majorities overturned liberal precedents.

\section{ConcLusion}

If in the future a majority of the Court believes that Seminole Tribe was wrongly decided, ${ }^{86}$ Justice Stevens's and Vicki Jackson's view of what the Court should do at that point if given the opportunity either to reaffirm

85. Many commentators would argue, see, e.g., supra note 84 , that the Court's decisions in the 2000 Presidential Election Cases are highly relevant to any assessment of the likelihood that any of the conservative Justices could be persuaded to display greater respect for precedent in the future. See Bush v. Gore, 531 U.S. 98 (2000); Bush v. Gore, 121 S.Ct. 512 (2000) (staying recount ordered by Florida Supreme Court); Bush v. Palm Beach County Canvassing Bd., 531 U.S. 70 (2000) (vacating and remanding decision of Florida Supreme Court holding that manual recounts were permissible, imposing deadline for return of ballot counts, and directing Florida Secretary of State to accept manual counts submitted prior to that deadline because of uncertainty as to precise grounds for its decision, including whether, and to what extent, state supreme court considered federal statute and federal constitutional provision governing appointment of electors). Nevertheless, the circumstances of those cases were so extraordinary that it may be unwise to look to them in attempting to draw generalizable conclusions, the willfulness of the conservative majority that many perceived in those decisions notwithstanding.

86. See supra note 25 and accompanying text for two possible scenarios under which such a majority could emerge. 
or overrule Seminole Tribe typifies that of those commentators who share their repugnance for the Court's Eleventh Amendment jurisprudence. ${ }^{87}$ The purpose of this Comment has not been to argne against this prescription on normative grounds, but rather to analyze and underscore some of its insufficiently considered positive implications. The Court's overruling of Seminole Tribe, like its overruling of Union Gas before it, would perpetuate a long-term trend of decision making that renders liberal and conservatives alike within and outside the Court worse off than they would be were the Court to display greater respect for stare decisis. Given the strategic environment in which the Justices are situated, this reality should cause all members of the legal community great concern, however they would view Seminole Tribe as an original matter. That is, it should give pause to both the most ardent supporters of the Court's decision in that case and to those who, like the author of this Comment, believe that Seminole Tribe was wrongly decided from the standpoints ${ }^{88}$ of constitutional text, ${ }^{89}$ original

\section{See supra text accompanying notes 1,61 .}

88. From the standpoint of economic analysis, Daniel Farber observes in the context of conducting a Coasian, positive-transaction-costs analysis of Seminole Tribe that

requiring consent from the state [before Congress may validly abrogate its immunity from suit] may involve significant transaction costs, legislative bodies being what they are. Those transaction costs only exist because of Seminole. So it is possible that some states will in the end be harmed by Seminole because political inertia will prevent them from entering into waiver bargains that actually would be in their interests. This is a perverse effect of Seminole but one of uncertain dimensions.

D. A. F., The Coase Theorem and the Eleventh Amendment, 13 Const. CoMmENT. 141, 142 (1996). At the same time, however, Farber notes that the anticipated effects of positive transaction costs also may serve to justify the Court's decision:

The second effeet of transaction costs may actually serve to justify the Seminole decision (which may be more than can be said of the majority opinion). We've been considering the situation where Congress wants to eliminate sovereign immunity more than the states desire to retain it. In that situation, Congress can bribe (or blackmail) the states to the efficient outcome, although transaction costs may sometimes block waivers by states that actually would prefer to accept the congressional bargains. But consider the contrary situation, where states desire to retain sovereign immunity more than Congress wants to eliminate it. Assume that, contrary to Seminole, Congress has the power to abrogate. Absent transaction costs, states could still bribe Congress to leave them immune. But actually, such dcals might be hard to negotiate, given that fifty states would have to offer bribes, rather than Congress offering a uniform dcal to every state. So Congress may be the "best briber," to use a phrase of Calabresi's. If so, then it makes sense to put the onus of offering the bribe on Congress rather than on the states, which means a doctrine of state waiver rather than one of congressional abrogation.

From a law and economics perspective, then, the correctness of Seminole seems to turn on a comparison of relative political transaction costs. Is it easier for Congress to offer the states incentives to waive immunity and for states then to make waiver decisions, or is it easier for the states to lobby Congress to remove liability? Assuming total transaction costs are lower when Congress does the bribing, then Seminole is defensible. In any event, the question turns on transaction costs, not on the history or text of the Eleventh Amendment.

Id. at 143 (footnotes omitted). Thus it appears that a theoretical economic analysis of Seminole Tribe is indeterminate, though an empirical economic analysis of relative costs would probably validate the decision.

Nevertheless, a Coasian analysis of the Court's Eleventh Amendment jurisprudence is of extremely limited constitutional relevance because prescriptive economic analysis focuses exclusively on the value of efficiency and completely ignores the distributive consequences of alternative legal 
intent, ${ }^{90}$ constitutional structure, ${ }^{91}$ sovereignty theory, ${ }^{92}$ constitutional history, ${ }^{93}$ stare decisis, ${ }^{94}$ and even the Court's symbolic concern about preservation of the states" "sovereign dignity" that largely has motivated

regimes-namely the distribution of power between the States and federal government. But, of course, it is precisely the latter and not the former that is fundamentally at stake in the constitutional debate over federalism in general and state sovereign immunity in particular. See Neil S. Siegel, Why the Eleventh Amendment Always Matters, Even When Transaction Costs Are Zero: A Reply to Professor Farber, 18 CONST. COMMENT. (forthcoming 2001).

89. The majority has conceded this issue. Supra note 65 .

90. Along with a basic awareness of the relevant historical background, one need only read the text of the Eleventh Amendment in order to understand what its Framers had in mind. They were saying politely that "Chisholm v. Georgia is hereby overruled." See Chisholm v. Georgia, 2 U.S. (2 Dall.) 419 (1793) (holding that Article 111, Section 2's State-Citizen Diversity Clause confers jurisdiction upon the federal courts in suits brought against a state by citizens of another state). See generally William A. Fletcher, A Historical Interpretation of the Eleventh Amendment: A Narrow Construction of an Affirmative Grant of Jurisdiction Rather than a Prohibition against Jurisdiction, 35 STAN. L. Rev. 1033 (1983).

91. See U.S. ConST. art. VI. It is difficult to see how valid federal law is the supreme law of the land in this federal system when the states may intentionally violate it with impunity. This is the reality of the situation in virtue of the fact that, in terms of both relative information possession and incentive effects, relying exclusively on the United States to enforce federal law means that many fewer state violations will be detected and remedied than if private citizens were allowed to sue the states for damages. That is, citizens potentially possess much more intimate knowledge of state violations than does the federal government, and without being able to sue for damages in addition to injuctive relief under Ex Parte Young, 209 U.S. 123 (1908), they have little incentive to discover the existence of such violations and inform the United States. Moreover, even if they do so inform the federal government, limited resources will often prevent it from bringing suits against the states.

92. In a federal system, are the states themselves the relevant sovereigns when they-like private actors-intentionally violate federal law that is unambiguously constitutional? On the other hand, the sovereign immunity of the United States extends to all causes of action, both state and federal. See, e.g., Cohens v. Virginia, 19 U.S. (6 Whcat.) 264, 411-12 (1821) ("The universally received opinion is, that no suit can be commenced or prosecuted against the United States ...." (Marshall, C.J.) (emphasis added)). Nevertheless, perhaps that fact indicates a problem with the latter and not the former.

93. Much could be said on this front. Suffice it to say here that the Court's state sovereign immunity jurisprudence, like its federalism crusade in general, constitutes an attempt to turn back the hands of time in terms of the balance of political power between the states and federal government. As Meltzer observes:

$[\mathrm{H}]$ istory tells us that siguificant constitutional limits on the scope of federal legislative power have proven difficult to erect and impossible to sustain. This point is most familiar with respect to the constitutional crisis in the 1930 s and the dramatic post-1937 withdrawal of serious limits on the reach of federal power. But Professor Rapaczynski reminds us that three other constitutional amendments have been precipitated by judicial efforts to enforce constitutional limits on the scope of federal power regarding such diverse subjects as slavery in the territories, the federal income tax, and the voting age in state elections. And during the brief ascendancy of National League of Cities, from 1976 to 1985, the Court was unable to apply the principle of state sovereiguty there announced with any bite.

Meltzer, supra note 10, at 64 (referring to Andrzej Rapaczynski, From Sovereignty to Process: The Jurisprudence of Federalism After Garcia, 1985 SuP. CT. REV. 341, 342-43) (footnotes omitted).

94. See supra text accompanying notes 56-59.

95. See Seminole Tribe v. Florida, 517 U.S. 44, 58 (1996) ("The Eleventh Amendment does not exist solely in order to 'preven[t] federal-court judgments that must be paid out of a State's treasury,' Hess v. Port Authority Trans-Hudson Corporation, 513 U.S. 30, 48 (1994); it also serves to avoid 'the indignity of subjecting a State to the coercive process of judicial tribunals at the instance of private parties,' Puerto Rico Aqueduct and Sewer Authority, 506 U.S. [139 (1993)], at 146 (internal quotation marks omitted)."); Alden v. Maine, 527 U.S. 706, 714-15 (1999) ("The federal system established by 
its approach to state sovereign immunity. ${ }^{96}$ Because this Comment's proposed solution to the collective action problem that the Justices face with respect to following precedent on this issue is necessarily contingent and will probably not be realizable any time soon in light of the behavior of the present conservative majority with respect to stare decisis, ${ }^{97}$ this inquiry's second, more modest, and more immediate purpose has been to underscore a significant hiatus in the critical debate over the Court's state sovereign immunity jurisprudence.

our Constitution preserves the sovereign status of the States" by "reserv[ing] to them a substantial portion of the Nation's primary sovereignty, together with the dignity and essential attributes inhering in that status.... The generation that designed and adopted our federal system considered immunity from private suits central to sovereign dignity."). The words "dignity" and "indignity" show up repeatedly in both Seminole and Alden.

96. Judge William Fletcher of the United States Court of Appeals for the Ninth Circuit writes that Seminole is "at least a partial mistake from the viewpoint of the five Justices in the majority," because

an argument in favor of state sovereign immunity is powerful when a state performs its sovereign functions, especially its policing and other criminal justice functions. But this argument has little or no force when a state engages in commercial activities. ... [R]egulation under the Commerce, Patent, and Copyright Clauses generally does not regulate a state in the performance of its sovereign functions.... [L]egislation passed under these clauses is virtually always directed at private actors, and brings a state within its scope only because the state engages in the same behavior as the private actors.

$\cdots$

... If the Court really believes that the distinction [between sovereign actions and commercial actions] is unimportant, we need to rethink a number of important legal ideas. Perhaps most obvious, those Justices in the current majority who voted for National League of Cities $v$. Usery need to rethink their rationale in that case. ... for the holding in National League of Cities depends on the distinction between activities of a state that involve its sovereignty and activities that do not. Further ... if the commercial activities of the states are the activities of sovereigns, the Court needs to rethink the market participant doctrine under the dormant Commerce Clause, under which a state is allowed to favor its own residents only when it is engaged in commercial activities.

Fletcher, supra note 61 , at 855 (footnotes omitted). While Fletcher's analysis has great force as a practical matter, it is likely that the conservative Justices are aware of the doctrinal tension-if not fiat inconsistency-he points out, and yet it is even more likely that they will not be much moved by his argument. The reason this is so probably comes down to a significant consideration he neglects to entertain-namely, the symbolic signifieance of state sovereigu immunity for the Justices in the majority. That is, in their minds, the "indignity" of "hailing" a "sovereign state" into court at the "behest" of a private citizen, to put it the way they like to do, far exceeds any symbolic damage to the state's sovereignty that results from the Court's Commerce Clause or dormant Commerce Clause jurispradence, the distinction between sovereign actions and commercial actions notwithstanding. From the standpoint of symbolism, what is more troubling than the Court's concern with affronts to sovereign "dignity" is the corrosive impact on rule-of-law values of the idea that the sovereign is above the law.

97. See supra note 20. 
